Биологические основы кормления

\title{
ФИЗИОЛОГИЧЕСКИЕ АСПЕКТЫ ПЕРЕВАРИВАНИЯ ПОЛНОСМЕШАННОГО РАЦИОНА В СЛОЖНОМ ЖЕЛУДКЕ ЖВАЧНЫХ НА ПРИМЕРЕ КРУПНОГО РОГАТОГО СКОТА (Bos taurus taurus)
}

\author{
Н.В. ВАСИЛЕВСКИЙ, Т.А. ЕЛЕЦКАЯ
}

Современные системы нормированного кормления крупного рогатого скота базируются на положении, что различные технологии скармливания не оказывают влияния на процессы переваривания и всасывания питательных веществ одного и того же рациона. В наших исследованиях впервые получены данные, свидетельствующие об изменениях параметров процесса переваривания рациона в сложном желудке крупного рогатого скота в зависимости от способа скармливания - раздельной выдачи каждого из кормов и их одновременной выдачи в виде полносмешанного рациона. Цель работы состояла в изучении динамики суточного потока химуса, его химического состава и переваримости основных групп питательных веществ у бычков при переходе на полносмешанный рацион. Опыты проводили на физиологическом дворе Института животноводства Украинской академии аграрных наук в 2015-2016 годах. Объектом исследований были кастрированные бычки (Bos taurus taurus) украинской красно-пестрой породы (живая масса 300 кг) с дуоденальными канюлями, установленными в начале 12-перстной кишки (ДПК). Определяли динамику суточного потока химуса, его химический состав и переваримость основных групा питательных веществ в сложном желудке. Исследования проводили по схеме латинского квадрата на двух рационах, различающихся по соотношению объемистых и концентрированных кормов, в два периода на одной группе животных (2 гол.). Объем поступающего химуса измеряли у каждого животного в 3-кратной повторности. Показано, что в результате перехода на полносмешанный рацион изменялся как характер поступления химуса в ДПК, так и переваримость питательных веществ в сложном желудке. Объем химуса в варианте с полносмешанным рационом в сравнении с раздельным кормлением увеличивался на $417 \pm 71$ мл/ч на высококонцентратном рационе (№ 1) и на $221 \pm 81$ мл/ч - на низкоконцентратном (№ 2), или соответственно на 14,42 и $8,36 \%(p<0,001)$. Полносмешанный рацион повышал поступление в ДПК Са, Р и общего минерального остатка (соответственно на 5,9; 10,1 и 8,5 \%). При этом установлено недостоверное увеличение количества Са в случае рациона № 1 и общей золы - для рациона № 2, по всем остальным показателям повышение было достоверным $(\mathbf{p}<0,05)$. Этот факт, а также обнаруженная тенденция к изменению концентрации Са и Р в составе дуоденального химуса позволяют предположить увеличение оттока химуса из рубца, обусловленное как усилением слюноотделения у животных, так и повышением потребления воды. Показано, что кормление бычков полносмешанным рационом вызывало разнонаправленные изменения переваримости всех питательных веществ: переваримость сырого жира и сырого протеина снижалась на обоих рационах (соответственно на 39,6 и 27,5 \%), сырой клетчатки - повышалась (на 6,9 \%), безазотистых экстрактивных веществ - существенно не изменялась на рационе № 1 , но имела тенденцию к снижению на рационе № 2, в результате чего общая переваримость сухого и органического вещества рациона изменялась незначительно. В качестве интегрального маркера оценки влияния полносмешанного рациона на рубцовое пищеварение следует рассматривать сырую клетчатку, поскольку она переваривается только в рубце и не синтезируется микрофлорой. В связи с этим установленное нами увеличение потока химуса при изменении способа скармливания при одном и том же типе рациона может снижать переваримость клетчатки вследствие ускоренного оттока в составе мелких частиц рубцовог содержимого, а при другом типе рациона, наоборот, увеличивать степень ее переваривания из-за улучшения условий ферментации.

Ключевые слова: скот украинской красно-пестрой породы, переваривание, объем химуса, клетчатка, полносмешанный рацион.

Переваривание питательных веществ корма у жвачных условно можно разделить на два процесса. С одной стороны, это превращения питательных веществ в преджелудках, где одновременно осуществляется переваривание частиц корма за счет ферментов, вырабатываемых симбиотической микрофлорой рубца, и синтез питательных веществ, составляющих сам микробиальный организм, с другой - переваривание в кишечнике собственными ферментами и всасывание питательных веществ во внутреннюю среду организма животного. Вторая стадия переваривания пищи 
начинается с сычуга, который служит аналогом желудка моногастричных. Разделение на микробиальное переваривание и собственное пищеварение достаточно условно: некоторые продукты поступают во внутреннюю среду макроорганизма непосредственно из преджелудков, а часть пищи переваривается микрофлорой тонкого и толстого кишечника $(1,2)$. Основная задержка кормовых масс происходит в рубце, поскольку их продвижение в следующие отделы пищеварительного тракта возможно только после измельчения до размера частиц около 1 мм (3-5).

В исследованиях многих авторов (6-8) было показано, что переход на кормление крупного рогатого скота полносмешанным рационом (ПСР) увеличивает общее потребление сухого вещества в сравнении с раздельной раздачей компонентов того же рациона. К другим положительным эффектам относится отсутствие возможности выборочного поедания кормов и снижение конкурентных взаимоотношений между животными (9-11). Ранее мы установили влияние технологии скармливания рациона на переваримость питательных веществ (12).

В представленной работе нами впервые получены данные об изменениях процесса пищеварения у молодняка крупного рогатого скота в зависимости способа скармливания одного и того же рациона. Так, при полносмешанном типе кормления переваримость сырого жира и сырого протеина снижалась как на высоко-, так и на низкоконцентратном рационе (соответственно на 39,6 и 27,5 \%), сырой клетчатки - повышалась (на $6,9 \%$, безазотистых экстрактивных веществ - существенно не изменялась для высоконцентратного рациона, но имела тенденцию к снижению для низкоконцентратного.

Цель работы состояла в изучении динамики суточного потока химуса, его химического состава и переваримости основных групп питательных веществ у бычков при переходе на полносмешанный тип кормления.

Методика. Опыты проводили на физиологическом дворе (Институт животноводства Украинской академии аграрных наук, 2015-2016 годы) на кастрированных бычки (Bos taurus taurus) украинской красно-пестрой породы (живая масса 300 кг) с дуоденальными канюлями, установленными в начале 12-перстной кишки (ДПК). Конструкция канюль обеспечивала сбор поступающего из сычуга в дуоденум химуса, его учет и возврат в пищеварительную систему (13). Кормление животных осуществлялось дважды в сутки (в $8^{00}$ и $\left.17^{00}\right)$ равными долями. Поток химуса измеряли в течение 9 ч после утреннего кормления. Полученные значения объема химуса за 9 ч экстраполировали на суточный интервал, что давало возможность рассчитывать переваримость питательных веществ в сложном желудке после химического анализа отобранных проб химуса и кормов рациона.

Влияние полносмешанного рациона на объем дуоденального химуса и переваримость питательных веществ в сложном желудке изучали по схеме латинского квадрата с двумя рационами, различающимися по соотношению объемистых и концентрированных кормов, в два периода на одной группе животных (2 гол.). Объем поступающего химуса измеряли у каждого животного в 3-кратной повторности.

Обменную энергию рационов рассчитывали по формуле:

ОЭк $=14,46-0,0007 \times \mathrm{CП}+0,0168 \times$ СЖ - 0,0192 $\times$ СК - 0,00028 $\times$ БЭВ, где СП, СЖ, СК, БЭВ - соответственно содержание сырого протеина, сырого жира, сырой клетчатки и безазотистых экстрактивных веществ в рационе, г/кг сухого вещества (СВ) рациона, ОЭк - концентрация обменной энергии, Мдж/кг СВ (14).

В первый период скармливали рацион, выдавая в кормушку сено и 
силос, а поверх силоса - сухие концентрированные корма. Адаптация пищеварения бычков к изучаемому рациону происходила за 14 сут. Затем в течение 14 сут измеряли поступление химуса в ДПК за 9-часовый интервал после утреннего кормления $(n=6)$. Между измерениями делали перерывы на 1-2 сут для отдыха животных. Во второй период (28 сут) предварительно измельченное сено, силос и комбикорм взвешивали и смешивали (для каждого животного индивидуально), используя смеситель барабанного типа (изготовлен в лаборатории механизации животноводческих процессов Института животноводства УААН). Такой прием обеспечивал выдачу всех компонентов рациона в виде ПСР каждому животному с той же точностью, что и при раздельном кормлении.

Поступления химуса в ДПК измеряли по описанной выше методике. Химический анализ основных питательных веществ рационов, химуса и кала проводили по стандартным методикам (15). Перед опытом и после него животных взвешивали.

Статистические расчеты, построение графиков и диаграмм проводили с помощью пакета лицензионных программ Office Standard 201032 bit Russian (лицензия GGWA-A) (https://www.microsoft.com/ru-ru/download/office.aspx) методами дисперсионного анализа. Вычисляли средние арифметические значения $(M)$, ошибки среднего ( $\pm \mathrm{SEM})$, среднее квадратическое отклонение $( \pm \sigma)$. Достоверность различий оценивали с помощью парного $t$-критерия Стьюдента (для сопряженных рядов), что позволило устранить системную ошибку, возникающую вследствие индивидуальных особенностей пищеварения животных.

Результаты. Рационы для подопытных животных составляли таким образом, чтобы их характеристики различались как можно значительнее (табл. 1). Это было сделано для того, чтобы оценить изменения физиологических параметров пищеварения под влиянием скармливания ПСР на фоне диаметрально противоположных условий, возникающих в рубце при низко- и высококонцентратных рационах. Различия в обеспеченности энергией и протеином между рационами составляли более $20 \%$.

1. Состав и характеристика высоко- и низкоконцентратных рационов в опытах на бычках (Bos taurus taurus) украинской красно-пестрой породы (Институт животноводства Украинской академии аграрных наук, 2015-2016 годы)

\begin{tabular}{|c|c|c|c|}
\hline \multirow{2}{*}{$\begin{array}{l}\text { Состав и характеристика } \\
\text { рациона }\end{array}$} & \multicolumn{2}{|c|}{ Рацион } & \multirow{2}{*}{$\begin{array}{l}\text { Сопоставление рационов по } \\
\text { характеристикам (рацион № } 2 \\
\text { к рациону № } 1, \%)\end{array}$} \\
\hline & $\begin{array}{l}\text { высококонцен- } \\
\text { тратный (№ 1) }\end{array}$ & $\begin{array}{l}\text { низкоконцен- } \\
\text { тратный (№ 2) }\end{array}$ & \\
\hline Силос кукурузный, кг & 11,00 & 16,80 & \\
\hline Сено люцерновое, кг & 1,00 & 2,08 & \\
\hline Дерть пшеничная, кг & 0,30 & - & \\
\hline Дерть кукурузная, кг & 0,30 & - & \\
\hline Жмых подсолнечниковый, кг & 3,30 & - & \\
\hline Дерть ячменная, кг & - & 0,72 & \\
\hline Минеральная добавка, кг & 0,03 & 0,03 & \\
\hline Сухое вешество, Г & 7008 & 6355 & 90,68 \\
\hline Органическое вещество, Г & 6615 & 5996 & 90,65 \\
\hline Зола, г & 393 & 359 & 91,28 \\
\hline Сырой протеин, г & 1413 & 501 & 35,48 \\
\hline Сырой жир, г & 563 & 112 & 19,80 \\
\hline Сырая клетчатка, г & 1955 & 2170 & 111,01 \\
\hline \multicolumn{4}{|l|}{ Безазотистые экстрактивные } \\
\hline вещества, г & 2684 & 3213 & 119,74 \\
\hline Кальций, г & 42,55 & 30,74 & 72,24 \\
\hline Фосфор, г & 25,62 & 21,18 & 82,67 \\
\hline Обменная энергия, МДж & 71,52 & 50,86 & 71,10 \\
\hline \multicolumn{4}{|l|}{ Содержание обменной } \\
\hline Энергопротеиновое & & & \\
\hline соотношение, г/МДж & 19,76 & 9,86 & 49,89 \\
\hline
\end{tabular}


П р и м е ч а и е. Обеспеченность основного обмена приводится в расчете на 1 кг метаболической массы тела (живая масса в степени 0,75). Прочерк означает отсутствие компонента в рационе.

Среднесуточный прирост живой массы за время исследований составил 1,12 и 0,26 кг при размахе колебаний $0,95-1,29$ и 0,21-0,32 кг соответственно на рационах № 1 и № 2, что согласуется с данными литературы $(16,17)$.

Поступление химуса из сложного желудка в ДПК происходит неравномерно. В моменты приема пищи объем химуса в единицу времени снижается в сравнении с периодом отдыха животного. На основании проведенных ранее измерений было установлено, что объем химуса за 9 ч после утреннего кормления составляет $37,47 \pm 0,97$ \% при коэффициенте вариации $3,73 \%$ относительно суточного объема, что практически совпадает с выбранным в эксперименте временным интервалом: 9:24 × $100 \%=37,5 \%$. Выбранный период значительно облегчал проведение исследований и, главное, снижал стрессовое воздействие на оперированных животных.

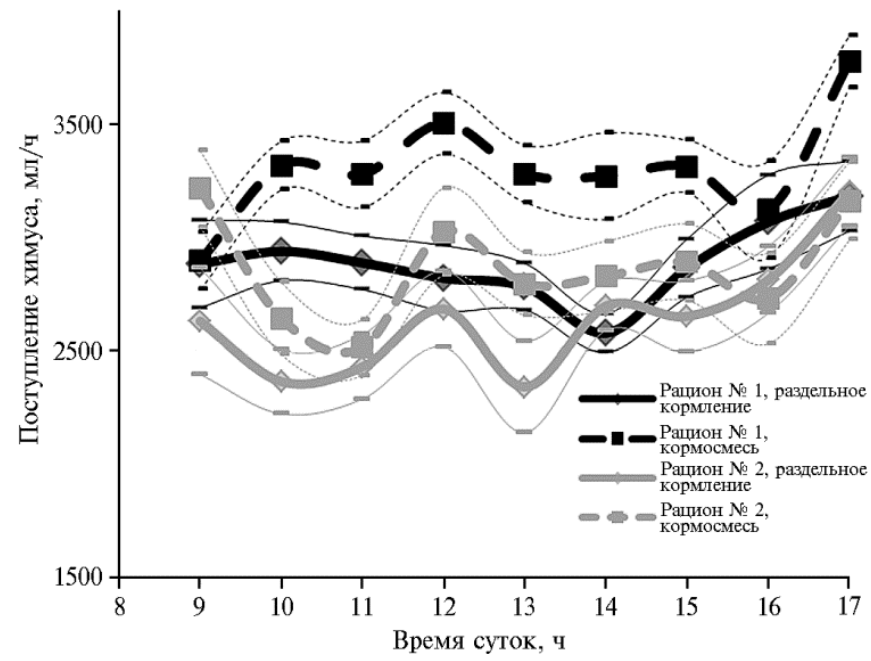

Динамика поступления химуса в 12-перстную кишку у бычков (Bos taurus taurus) украинской красно-пестрой породы при раздельном кормлении и содержании на полносмешанном рационе. Описание рационов и условия проведения опытов см. в разделе «Методика» (Институт животноводства Украинской академии аграрных наук, 2015-2016 годы).

При переходе на ПСР характер поступления химуса в ДПК и переваримость питательных веществ в сложном желудке изменялись. В течение всего опыта скорость поступления химуса из сычуга в 12перстную кишку была выше при использовании ПСР (рис.). В среднем за 1 ч объем химуса при кормлении полносмешанным рационом увеличивался в сравнении с раздельным кормлением на $417 \pm 71$ мл (рацион № 1) и $221 \pm 81$ мл (рацион № 2), или соответственно на 14,42 и $8,36 \%$ $(\mathrm{p}<0,001)$. С ПСР во всех случаях наблюдались не только достоверные изменения объема химуса, но и увеличение скорости прохождения минеральных веществ из сложного желудка в ДПК.

Скармливание ПСР усиливало поступление в ДПК кальция, фосфора и общего минерального остатка (табл. 2). При этом было установлено недостоверное, на уровне тенденции $(0,1>\mathrm{p}>0,05)$, увеличение количества Са для рациона № 1 и общей золы - для рациона № 2, по всем остальным показателям повышение было достоверным ( $<<0,05)$. Концентрация минеральных веществ в поступающем химусе, за исключением Са, при переходе на ПСР № 2 снижалась. Это происходило на фоне заметного повышения общей минерализации дуоденального химуса. Отсюда можно сделать вывод, что скармливание корма в виде ПСР в большей степени 
2. Количество минеральных веществ в химусе в начальном участке 12-перстной кишки у бычков (Bos taurus taurus) украинской красно-пестрой породы при раздельном и полносмешанном типе кормления (Институт животноводства Украинской академии аграрных наук, 2015-2016 годы)

\begin{tabular}{|c|c|c|c|c|c|c|}
\hline \multirow{2}{*}{ Рацион } & \multicolumn{3}{|c|}{ Раздельное кормление } & \multicolumn{3}{|c|}{ Полносмешанный рацион } \\
\hline & $\mathrm{Ca}$ & $\mathrm{P}$ & зола & $\mathrm{Ca}$ & $\mathrm{P}$ & зола \\
\hline \multicolumn{7}{|c|}{ Поступил о в 12 - пе рст ную к иш ку, г/сут } \\
\hline № 1 & 60,71 & 48,99 & 602,5 & $64,27^{*}$ & $53,94^{* *}$ & $653,5^{* *}$ \\
\hline № 2 & 60,35 & 38,70 & 615,3 & $71,75^{* * *}$ & $42,16^{* * * *}$ & 669,5 \\
\hline \multicolumn{7}{|c|}{ м ин ералов в $\quad$ хи м ус е, мг\% } \\
\hline № 1 & 87,68 & 70,51 & 868,0 & $81,75^{* *}$ & 68,57 & $832,4^{* * * *}$ \\
\hline № 2 & 96,88 & 61,94 & 982,1 & $104,51^{* * *}$ & $61,03^{*}$ & 971,0 \\
\hline \multicolumn{7}{|c|}{$\begin{array}{l}\text { Пр и м е ч а н е. Описание рационов и условия проведения опытов см. в разделе «Методика». } \\
\text { * Различия для полносмешанного рациона с показателями при раздельном кормлении статистически } \\
\text { недостоверны }(0,1>\mathrm{p}>0,05) \text {. } \\
\text { **, ***, **** Различия для полносмешанного рациона с показателями при раздельном кормлении стати- } \\
\text { стически значимы соответственно при } \mathrm{p}<0,05 ; \mathrm{p}<0,01 \text { и } \mathrm{p}<0,001 \text {. }\end{array}$} \\
\hline
\end{tabular}

Дисперсионный анализ (табл. 3) выявил заметное влияние (более $50 \%$ по шкале Чеддока, Cheddock scale) способа скармливания на поступление Р (оба рациона) и Са (рацион № 2) в ДПК. При этом изученные факторы (состав рациона и форма скармливания) влияли на общее содержание минерального остатка в химусе ДПК.

3. Дисперсионный анализ влияния способа скармливания и состава рационов на поступление минеральных веществ в химус 12-перстной кишки у бычков (Bos taurus taurus) украинской красно-пестрой породы (Институт животноводства Украинской академии аграрных наук, 2015-2016 годы)

\begin{tabular}{|c|c|c|c|c|}
\hline \multirow{2}{*}{ Фактор } & & \multicolumn{3}{|c|}{ Степень влияния, \% } \\
\hline & & $\mathrm{Ca}$ & $\mathrm{P}$ & зола \\
\hline \multicolumn{5}{|c|}{ Состав рациона } \\
\hline Рацион № 1 & & 10,5 & 57,8 & 12,3 \\
\hline \multirow{2}{*}{ Рацион № 2} & & 59,2 & 52,8 & 13,7 \\
\hline & С по с об б & ск а рм ли и ания & & \\
\hline Раздельное кормление & & 23,3 & 48,8 & 12,8 \\
\hline Полносмешанный рацион & & 46,4 & 61,8 & 13,2 \\
\hline
\end{tabular}

По данным о составе секрета слюнных желез (18-20), в слюне у коров из катионов преобладает $\mathrm{Na}-126$ мэкв/л (до $85 \%$ ) и только 6 мэкв/л (4 \%) приходится на долю К. Поступление Са и $\mathrm{Mg}$ со слюной имеет меньшее значение для ионного равновесия. Ионы Са содержатся в количестве от 0,2 до 0,5 мэкв/л. Среди анионов особую важность имеют бикарбонаты (103-125 мэкв/л) и фосфаты (25-64 мэкв/л), определяющие щелочные свойства слюны $(18,21)$. Высокая щелочность, обусловленная содержанием бикарбонатов и фосфатов, необходима для нейтрализации кислот, образующихся в преджелудках в результате брожения. Состав слюны характеризуется относительным постоянством (22-24), а изменения в поступлении ее компонентов связаны с изменением общего количества слюны. По-видимому, это обусловлено тем, что слюна имеет мицеллярное строение. Мицелла состоит из ядра, основой которого служит фосфат кальция. Ядро окружено ионами гидрофосфата и наружной диффузной оболочкой на основе ионов кальция (25).

Исходя из достоверного увеличения поступления Р в ДПК для обоих рационах, Са - для рациона № 2 и общей золы - для рациона № 1 (см. табл. 2), можно предположить, что увеличение оттока химуса из рубца в наших опытах связано с усилением слюноотделения. В то же время полученные данные о некотором снижении концентрации изученных минера- 
шалась. Переваримость безазотистых экстрактивных веществ (БЭВ) в случае рациона № 1 существенно не изменялась, рациона № 2 - имела тенденцию к снижению. По нашему мнению, ускоренный отток жидкой фракции из рубца положительно влиял на рубцовую микрофлору, особенно целлюлозолитическую. Об этом свидетельствуют достоверные различия по СП и СК между раздельным кормлением и ПСР в случае рациона № 1 и различия на уровне тенденции $(0,1>\mathrm{p}>0,05)$ - в случае рациона № 2 . Активное развитие популяции микрорганизмов рубца приводило к повышению доли вновь синтезированных микробиальных СЖ и СП в поступающем из преджелудков химусе. Это сказалось на снижении видимой переваримости этих групп питательных веществ при кормлении ПСР для СЖ (на уровне тенденции), а для СП - достоверно (р < 0,05) (см. табл. 4). При использовании рациона № 2 с низким содержанием концентратов и значительной долей объемистых кормов синтез микробиального СЖ и СП превышал потребление этих групп питательных веществ с кормами. В таком случае правильнее оценивать не переваримость, а доступность питательных веществ для переваривания в тонком кишечнике, то есть количество питательных веществ, поступивших в ДПК, по отношению к потребленным с кормом. Доступность СЖ рациона № 2 составляла при раздельном кормлении $156 \%$, при ПСР - 147 \%; СП - соответственно 120 и $138 \%$.

Повышенное количество СЖ, поступающих из сложного желудка в ДПК, по сравнению с содержащимся в потребленном корме было связано с преобразованием одних веществ в другие в процессе жизнедеятельности микробиальной популяции рубца. При этом жиров, вновь синтезированных из углеводов и углеводных скелетов дезаминированных аминокислот, образовывалось больше, чем содержалось в потребленном корме. Повышенное содержание азотистых веществ в поступающем в ДПК химусе также было следствием микробиального синтеза, однако происхождение дополнительного азота по отношению к поступившему с кормом объясняется его рециркуляцией внутри организма.

В результате дезаминирования аминокислот в процессе основного обмена в тканях организма образуется аммиак, токсичный для клетки. Для его обезвреживания выработан энергозатратный механизм синтеза мочевины из трех свободных аминогрупп (29). Следует отметить, что синтез мочевины происходит не только в печени животных, но и непосредственно в стенке рубца (30-32). Синтезированная таким образом мочевина поступает в кровь и составляет так называемый пул мочевины, из которого она частично направляется в рубец, а частично выводится с мочой. Основным механизмом, направляющим мочевину в рубец, служит ее экскреция со слюной. При попадании в рубец мочевина разрушается уреазами микрофлоры до аммиака, который используется в процессах микробиального синтеза для образования аминокислот и последующего синтеза микробного и протозойного белка. Наиболее эффективно проходит экскреция мочевины в околоушной железе (20-30 мг\%), содержание этого соединения в крови составляет 10-15 мг\%, в секрете подчелюстной и подъязычной желез - соответственно 10-15 и 8-10 мг\% (33). В зависимости от интенсивности и равномерности образования мочевины в течение суток соотношение ее рециркуляции и выведения может существенно изменяться. Значительную роль в этом играет наличие в рационе животного доступной для использования микрофлорой энергии, особенно легкопереваримых углеводов (34).

Исходя из результатов нашего опыта, на синтез микробиального 
СП влияет как кормовой фактор, так и интенсивность поступления в рубец мочевины в составе слюны. Так, в случае рациона № 1 после перехода на ПСР переваримость СП в рубце достоверно повысилась, что свидетельствует о снижении вовлечения мочевины в процесс рециркуляции азота и ее более активном выведении из организма. Другими словами, количество доступного азота в рубце не обеспечивалось соответствующим количеством энергии для синтеза микробиального сырого протеина. При использовании рациона № 2 потенциальная обеспеченность микрофлоры доступной энергией была выше, как следствие, эндогенный азот тоже вовлекался в микробиальный синтез. Усиление слюноотделения, вызванное ПСР, и связанное с этим повышенное поступление мочевины в рубец способствовало дополнительному синтезу микробиального СП, что отразилось на увеличении поступления СП в ДПК.

Мы уже отмечали, что усиленный отток жидкости из сложного желудка при переходе на ПСР положительно влиял на микробиальную популяции рубца. Это наблюдалось как на высококонцентратном рационе, когда отмечается повышенная кислотность вследствие синтеза значительного количества пропионовой кислоты, так и на низкоконцентратном с преобладанием уксуснокислого типа брожения, характерного для переваривания волокнистых кормов, богатых клетчаткой. Однако этот механизм имел некоторые различия в зависимости от состава рациона. В первом случае усиленный отток жидкости из рубца регулировал микробиальный синтез посредством снижения концентрации продуктов жизнедеятельности микрофлоры, во втором - за счет повышения содержания используемых субстратов.

Следует учитывать, что с усиленным оттоком жидкости из рубца ускоряется удаление тонкоизмельченной нерастворимой фракции частиц кормов. Можно предположить, что усиление этого фракционного оттока уменьшало бы время микробиального ферментирования частиц корма, что неизбежно должно было приводить к снижению видимой переваримости питательных веществ. В наших опытах наблюдалось повышение переваримости БЭВ и снижение переваримости СЖ на рационе № 1 при снижении переваримости БЭВ и повышении переваримости СЖ на рационе № 2. Повидимому, рост интенсивности микробиальной ферментации в одном случае был достаточно высок и преобладал над снижением переваримости вследствие повышенной скорости оттока, а в другом, наоборот, снижение переваримости из-за увеличения фракционной скорости оттока не компенсировалось микробиальным синтезом, что и отразилось на повышении общей видимой переваримости.

Еще одним трудно учитываемым механизмом влияния усиленного слюноотделения на процессы микробиальной ферментации в рубце является тот факт, что у жвачных животных слюна имеет сравнительно низкое поверхностное натяжение (почти в 1,5 раза ниже, чем у воды). Это свойство слюны препятствует образованию пенистой массы в рубце и сетке. Низкое поверхностное натяжение слюны губительно действует на отдельные виды бактерий, следовательно, она может участвовать в регуляции видового состава микроорганизмов, населяющих преджелудки. Это, в свою очередь, оказывает влияние на интенсивность расщепления тех или иных компонентов клеток растительных кормов и накопление в рубцовой жидкости вновь синтезированных микробиальных жира и протеина.

Адекватная интерпретация полученных данных невозможна без 
учета того, что питательные вещества в рубце не только разрушаются, но и, вновь синтезируясь, накапливаются в составе микробиальной биомассы. Для оценки взаимодействия ускоренного фракционного оттока мелких частиц корма и улучшения условий ферментации вследствие ускоренного удаления продуктов микробиального брожения в качестве маркера следует рассматривать сырую клетчатку, поскольку она только переваривается в рубце и микрофлорой не синтезируется. В связи с этим установленное нами увеличение потока химуса при изменении способа скармливания на одном и том же типе рациона может снижать переваримость клетчатки вследствие ускоренного оттока в составе мелких частиц рубцового содержимого, тогда как при другом типе рациона, наоборот, увеличивать степень ее переваривания из-за улучшения условий ферментации (сдвиг рН в щелочную сторону).

Таким образом, у бычков украинской красно-пестрой породы в результате перехода на полносмешанный рацион (ПСР) изменялся характер поступления химуса в 12-перстную кишку и переваримость питательных веществ в сложном желудке. Объем химуса при ПСР с высоким содержанием энергии достоверно увеличивался на $417 \pm 71$ мл/ч, с низким - на $221 \pm 81$ мл/ч. Применение ПСР повышало поступление кальция, фосфора и общего минерального остатка в 12-перстную кишку. Установленный рост поступления минеральных компонентов в составе дуоденального химуса и изменение их концентрации свидетельствуют, что при переходе на ПСР увеличивается отток жидкости из сложного желудка как за счет усиления слюноотделения, так и за счет других механизмов повышения поступления воды в сложный желудок. Переваримость всех питательных веществ в сложном желудке при ПСР изменялась разнонаправлено: по сырому жиру и сырому протеину - снижалась на обоих рационах, по сырой клетчатке - повышалась, по безазотистым экстрактивным веществам при использовании высококонцентратного рациона - существенно не изменялась, низкоконцентратного - имела тенденцию к снижению, в результате чего общая переваримость сухого вещества и органического вещества рациона изменялась незначительно. В качестве интегрального маркера для оценки влияния ПСР на рубцовое пищеварение возможно использование показателя переваримости сырой клетчатки.

\section{ЛИТЕРАТУРА}

1. Golder H.M., Denman S.E., McSweeney C., Wales W.J., Auldist M.J., Wright M.M., Marett L.C., Greenwood J.S., Hannah M.C., Celi P., Bramley E., Lean I.J. Effects of partial mixed rations and supplement amounts on milk production and composition, ruminal fermentation, bacterial communities, and ruminal acidosis. J. Dairy Sci., 2014, 97(9): 5763-5785 (doi: 10.3168/jds.2014-8049).

2. Auldist M.J., Marett L.C., Greenwood J.S., Hannah M., Jacobs J.L., Wales W.J. Effects of different strategies for feeding supplements on milk production responses in cows grazing a restricted pasture allowance. J. Dairy Sci., 2013, 96(2): 1218-1231 (doi: 10.3168/jds.2012-6079).

3. Mertens D.R. Creating a system for meeting the fiber requirements of dairy cows. J. Dairy Sci., 1997, 80(7): 1463-1481 (doi: 10.3168/jds.S0022-0302(97)76075-2).

4. Teimouri Y.A., Valizadeh R., Naserian A., Christensen D.A., Yu P., Eftekhari Shahroodi F. Effects of alfalfa particle size and specific gravity on chewing activity, digestibility, and performance of Holstein dairy cows. J. Dairy Sci., 2004, 87(11): 3912-3924 (doi: 10.3168/jds.S00220302(04)73530-4).

5. Mirzaei-Aghsaghali A., Maheri-Sis N. Importance of "physically effective fibre" in ruminant nutrition: a review. Annals of Biological Research, 2011, 2(3): 262-270.

6. Keunen J.E., Plaizier J.C., Kyriazakis I., Duffield T.F., Widowski T.M., Lindinger M.I., McBride B.W. Effects of a subacute ruminal acidosis model on the diet selection of dairy cows. 
J. Dairy Sci., 2002, 85(12): 3304-3313 (doi: 10.3168/jds.S0022-0302(02)74419-6).

7. Spiekers H., Potthast V. Erfolgreiche Milchviehfütterung. DLG-Verl., Frankfurt am Main, 2004.

8. Khan M.A., Bach A., Castells L., Weary D.M., von Keyserlingk M.A.G. Effects of particle size and moisture levels in mixed rations on the feeding behavior of dairy heifers. Animal, 2014, 8(10): 1722-1727 (doi: 10.1017/S1751731114001487).

9. Kononoff P.J., Heinrichs A.J., Lehman H.A. The effect of corn silage particle size on eating behaviour, chewing activities and rumen fermentation in lactating dairy cows. J. Dairy Sci., 2003, 86(10): 3343-3353 (doi: 10.3168/jds.S0022-0302(03)73937-X).

10. Rottman L.W., Ying Y., Zhou K, Bartell P.A., Harvatine K.J. The effects of feeding rations that differ in neutral detergent fiber and starch concentration within a day on production, feeding behavior, total-tract digestibility, and plasma metabolites and hormones in dairy cows. J. Dairy Sci., 2015, 98(7): 4673-4684 (doi: 10.3168/jds.2014-8859).

11. Kmicikewycz A.D., Harvatine K.J., Heinrichs A.J. Effects of corn silage particle size, supplemental hay, and forage-to-concentrate ratio on rumen $\mathrm{pH}$, feed preference, and milk fat profile of dairy cattle. J. Dairy Sci., 2015, 98(7): 4850-4868 (doi: 10.3168/jds.2014-9249).

12. Василевский Н.В., Елецкая Т.А. Цюпко В.В, Берестовая Л.Е. Влияние технологии скармливания и уровня сырого протеина в рационе на переваримость питательных веществ. Проблемы биологии продуктивных животных, 2013, 1: 67-74.

13. Алиев А.А. Новейшие оперативные методы исследования жввачных жсивотных. М., 1985.

14. Валигура В.И. Закономерности переваривания и использования питательных веществ и энергии разноструктурных рационов овцами. Докт. дис. М., 1990.

15. Лабораторні методи досліджень у біології, тваринництві та ветеринарній медицині. Львів, 2012.

16. Цюпко В.В., Пронина В.В., Берус М.В. и др. Методические рекомендации по нормированию энергии в кормлении крупного рогатого скота. Харьков, 1989.

17. AFRC Technical Committee on Responses to Nutrients, Report number 5, Nutritive requirements of ruminant animals: energy. Nutrition Abstracts and Reviews. Series B, Livestock Feeds and Feeding, 1990, 60(10): 729-804.

18. Physiology of Digestion and Metabolism in the Ruminant. Proc. of the Third International Symposium, Cambridge, England, August 1969 /A.T. Phillipson (ed.). Oriel Press Limited., 1970.

19. Чичилов А.В. Выделение макроэлементов околоушными слюнными железами лактирующих коров в связи с рубцовым метаболизмом. Автореф. канд. дис. М., 1984.

20. Ishler V.A., Heinrichs A.J., Varga G.B. From feed to milk: understanding rumen function. Pennsylvania State University, 1996.

21. Beal A.M. Salivary electrolyte concentrations and electrical potential difference across the parotid salivary duct of anaesthetized sodium-replete sheep. Australian Journal of Biological Sciences, 1980, 33(2): 197-204.

22. Рузанов В.Е. Обмен калия, натрия и хлора у коров черно-пестрой, голштино-фризской пород и их помесей. Автореф. канд. дис. М., 2002.

23. Алиев А.А. Достижения физиологии пищеварения сельскохозяйственных животных в XX веке (основные концепции). Сельскохозяйственная биология, 2007, 2: 12-23.

24. Tirloni L., Reck J., Terra R.M., Martins J.R., Mulenga A., Sherman N.E., Fox J.W., Yates III J.R., Termignoni C., Pinto A.F.M., Vaz I.daS. Jr. Proteomic analysis of cattle tick Rhipicephalus (Boophilus) microplus saliva: a comparison between partially and fully engorged females. PLoS ONE, 2014, 9(4): e94831 (doi: 10.1371/journal.pone.0094831).

25. Боровский Е.В., Леонтьев В.С. Биология полости рта. М., 1991.

26. Olsson K., McKinley M.J. Central control of water and salt intake in goats and sheep. In: $D i-$ gestive physiology and metabolism in ruminants /Y. Ruckebusch, P. Thivend (eds.). Springer, Dordrecht, 1980: 161-175 (doi: 10.1007/978-94-011-8067-2_8).

27. Schröder B., Vössing S., Breves G. In vitro studies on active calcium absorption from ovine rumen. Journal of Comparative Physiology B, 1999, 169(7): 487-494 (doi: 10.1007/s003600050246).

28. Grabherr H., Spolders M., Lebzien P., Hüther L., Flachowsky G., Fürll M., Grün M. Effect of zeolite A on rumen fermentation and phosphorus metabolism in dairy cows. Archives of Animal Nutrition, 2009, 63(4): 321-336 (doi: 10.1080/17450390903020430).

29. Ёрсков Э.Р., Рил М. Энергетическое питание жвачных животных. Боровск, 2003.

30. Mutsvangwa T., Davies K.L., McKinnon J.J., Christensen D.A. Effects of dietary crude protein and rumen-degradable protein concentrations on urea recycling, nitrogen balance, omasal nutrient flow, and milk production in dairy cows. J. Dairy Sci., 2016, 99(8): 6298-6310 (doi: 10.3168/jds.201610917).

31. Sun F., Aguerre M.J., Wattiaux M.A. Starch and dextrose at 2 levels of rumen-degradable protein in iso-nitrogenous diets: effects on lactation performance, ruminal measurements, methane emission, digestibility, and nitrogen balance of dairy cows. J. Dairy Sci., 2019, 102(2): 12811293 (doi: $10.3168 /$ jds.2018-15041). 
32. Fessenden S.W., Foskolos A., Hackmann T.J., Ross D.A., Block E., Van Amburgh M.E. Effects of a commercial fermentation byproduct or urea on milk production, rumen metabolism, and omasal flow of nutrients in lactating dairy cattle. J. Dairy Sci., 2019, 102(4): 3023-3035 (doi: 10.3168/jds.2018-15447).

33. Скопичев В.Г., Яковлев В.И. Частная физиология. Ч. 2. Физиология продуктивных животных. М., 2008.

34. Василевский Н.В. Доступность сырого протеина для переваривания в тонком кишечнике $и$ поступление эндогенного азота в сложный желудок бычков. Канд. дис. Харьков, 1993.

\author{
Институт жсивотноводства \\ Национальной академии аграрных наук Украины, \\ 61120 Украина, г. Харьков, ул. 7-й Гвардейской Армии, 3, \\ e-mail: vasilevskii.n@mail.ru $₫$, eletskatat@zandex.ru
}

Поступила в редакцию

22 марта 2019 года

Sel'skokhozyaistvennaya biologiya [Agricultural Biology], 2019, V. 54, № 4, pp. 787-797

\title{
PHYSIOLOGICAL ASPECTS OF COMPLETE MIXED DIET DIGESTION IN COMPLEX STOMACH OF RUMINANTS ON THE EXAMPLE OF CATTLE (Bos taurus taurus)
}

\author{
N.V. Vasilevskiy, T.A. Yeletskaya
}

Institute of Animal Science of National academy of agrarian sciences of Ukraine, 3, vul. 7-i Gvardeiskoi Armii, Kharkov, 61120 Ukraine, e-mail vasilevskii.n@mail.ru ( $₫$ corresponding author), eletskatat@zandex.ru ORCID:

Vasilevskiy N.V. orcid.org/0000-0002-7437-2910

The authors declare no conflict of interests

Yeletskaya T.A. orcid.org/0000-0001-8980-6972

Received March 22, 2019

doi: 10.15389 /agrobiology.2019.4.787eng

\section{Abstract}

Modern systems of normalized cattle feeding are based on the position that different feeding technologies do not affect the processes of digestion and absorption of nutrients of the same diet. In our studies, data were obtained for the first time, indicating changes in the parameters of the ration digestion process in the complex stomach of cattle, depending on the method of feeding: separate delivery of separate feeds and simultaneous delivery by the form of the Total Mixed Ration (TMR). To determine mechanisms of increasing feed dry matter intake in cattle when they were switched to Total Mixed Ration feeding, daily flux rates of chyme, its chemical composition and digestibility of main nutrient groups in the compound stomach of young cattle were studied. A Latin square design experiment was carried out using two diets differing in the forage fodder to concentrated fodder ratio and two methods of feeding (separate distribution of feed and in the form of TMR) by the method of periods with two Ukrainian red-motley bulls (Bos taurus taurus) of $300 \mathrm{~kg}$ live weight, with a sluice T-shaped duodenal canula. As a result of switching to the TMR feeding, both the nature of chyme influx to the duodenum and nutrient digestibility in the complex stomach were found to change. For 1 hour, the volume of chyme during TMR feeding increased by $417 \pm 71 \mathrm{ml} / \mathrm{h}$ as compared to separate high concentrate diet feeding, while compared with low concentrate feeding, it increased by $221 \pm 81 \mathrm{ml} / \mathrm{h}$, or by $14.42 \%$ and $8.36 \%$, respectively $(\mathrm{p}<0.001)$. TMR increased $\mathrm{Ca}, \mathrm{P}$ and total mineral residue influx to the duodenum (by $5.9 \%, 10.1$ and $8.5 \%$, respectively). At that, the increase in $\mathrm{Ca}$ with the first diet and in general ash with the second one was established at a level of trend, whereas for all the others the increase was significant $(p<0.05)$. This fact as well as the observed tendency to a change in the $\mathrm{Ca}$ and $\mathrm{P}$ concentrations in the duodenal chyme composition suggest an increase in the outflow of chyme from the rumen caused by both increased salivation and consumption of water by the animals. The feeding of animals with the TMR was shown to cause multidirectional changes in digestibility of all nutrients: digestibility of raw fat and crude protein decreased in both diets (by $39.6 \%$ and $27.5 \%$, respectively), while digestibility of crude fiber increased (by $6.9 \%$ ); digestibility of nitrogen-free extractives did not change significantly in the first diet, whereas it tended to decrease in the second one so that the total digestibility of the dry and organic matter of the diet changed insignificantly. Raw fiber should be considered as an integral marker for assessing the TMR effect for rumen's digestion, since it is only digested in the rumen and is not synthesized by the microflora. Due to this, the increase in the chyme flow that we established, when we changed feeding method in the same type of diet, can reduce fiber digestibility due to accelerated outflow of rumen's content with small particles, whereas with the other type of diet, on the contrary, can increase digestion due to improvement of fermentation conditions.

Keywords: Ukrainian red-motley cattle, digestion, chyme volume, fiber, total mixed ration. 